\title{
Variation of the Chemical Composition of Thymus Vulgaris Essential Oils by Phenological Stages
}

\author{
CRISTIAN MOISA ${ }^{1,2}$, ANDREEA LUPITU1,2, GEORGETA POP², DORINA RODICA CHAMBRE ${ }^{1}$, LUCIAN COPOLOVICI ${ }^{1}$, \\ GABRIELA CIOCA ${ }^{3 *}$, SIMONA BUNGAU4*, DANA MARIA COPOLOVICl ${ }^{1}$ \\ ${ }^{1}$ Aurel Vlaicu University, Faculty of Food Engineering, Tourism and Environmental Protection; Institute for Research, Development \\ and Innovation in Technical and Natural Sciences, Romania, 2 Elena Dragoi Str., 310330, Arad, Romania \\ ${ }^{2}$ Banat University of Agricultural Sciences and Veterinary Medicine King Michael $1^{\text {st }}$ of Romania from Timisoara, 119 Calea \\ Aradului Str., Timisoara, Romania \\ ${ }^{3}$ Lucian Blaga University of Sibiu, Faculty of Medicine, 10 Victoriei Blvd., 550024, Sibiu, Romania \\ ${ }^{4}$ University of Oradea, Faculty of Medicine and Pharmacy, 29 N. J iga Str., 410028, Oradea, Romania
}

\begin{abstract}
Thymus vulgaris essential oil is one of the most common oils used mainly in food industry but it could also have applications in medicine and pharmacy. The chemical composition of this essential oil depends on the plant material harvesting time, phenomenological stages, meteorological conditions and growing area of plants. In our study, four different Thymus vulgaris L. var. Donne Valley essential oils have been extracted and characterised. The essential oils have been extracted from plants before and after flowering in two different years. There is an important difference between the chemical composition of oils obtained from plants harvested before and afterflowering. Thymol and carvacrol have been found as the major components, but the percentage depends on the phenological stages of the plants and the year of harvesting. Furthermore, the composition of the minor components changed.
\end{abstract}

Keywords: essential oils, chemical composition, Thymus vulgaris L., phenological stages of plants

A lot of papers in the scientific literature focus on the content of essential oils and other components (especially antioxidant and therapeutics) existing in different parts of plants [1-7], these oils having numerous and diverse uses since ancienttimes [8]. Thymus vulgaris L. var. Donne Valley is a woody-based perennial evergreen subshrub rich in essential oil stored in glandular peltate trichomes located on both sides of the leaves, that blooms in clusters of pink and purple flowers in early summer (J une and J uly) [9-13]. It belongs to the Lamiaceae family and is indigenous to the southern part of Europe and the Mediterranean area [6]. Both thymi herba (aerial plant parts) and thymi aetheroleum (thyme essential oil) are used in food industry as spices, pharmaceutics and medicine, cosmetics and perfumery $[9,10,14-17]$.

The pharmacological properties of thyme essential oil rely mostly on the phenolic monoterpenes thymol and carvacrol which are the major components found, but different chemotypes can also appear depending on the harvesting time, phenological stages, altitude, weather conditions $[10,18]$. These monoterpenic phenols act as natural bioactive compounds with strong antibacterial, antifungal, antitumor, anti-inflamatory, antiviral and antioxidant properties $[9,13,18-22]$.

Chemical polymorphism is usual in Lamiaceae family when one or more chemotypes have been observed in Thymus species in accordance with the major component determined in the essential oil $[23,24]$. Thymol and carvacrol are the most frequent chemotypes of thyme species indicating them as major components of thyme essential oils, having the same molecular weight ( $M=150$ g. $\mathrm{mol}^{-1}$ ) but with a different $\mathrm{OH}$ group position at the phenolic ring (meta and ortho). Thymol and carvacrol are attended by two precursors: $p$-cymene and $\gamma$-terpinene [ 10 , 25].
The aim of this study was to analyze the variations in chemical composition depending on phenological stages and different vegetation cycles (over a period of two years) for Thymus vulgaris $\mathrm{L}$. var. Donne Valley. For this purpose, essential oils were obtained before and after flowering stages in two different years (2017 and 2018) under different meteorological conditions. The results obtained in this paper are meant to complete previous work reported by other authors $[10,14,16,19,20,23]$ in relation to occurring differences in the chemical composition of thyme essential oils influenced by phenological or weather conditions.

\section{Experimental part}

Materials and methods

Plant material

Aerial parts (thymi herba) of Thymus vulgaris L. var. Donne Valleywere harvested in two different phenological stages: in late May before flowering and in June after flowering in the course of two different years (2017 and 2018) from Lovrin Agricultural Research and Development Resort, Lovrin commune, Timis county - $20^{\circ} 47^{\prime}$ E longitude and $45^{\circ} 57^{\prime} \mathrm{N}$ latitude. Gathered plant material was placed in a well-ventilated room, away from direct sunlight, to airdry for a period of two weeks. Dried plant material was stored in untreated brown paper bags until essential oil extraction and further analysis were performed. For each phenological stage a sample of the specimen was kept at the Institute of Technical and Natural Sciences ResearchDevelopment-Innovation of Aurel Vlaicu University of Arad.

\section{Essential oil extraction}

Leaves and flowers were removed from the aerial parts of thymi herba and were placed on the grid found in the column of a $5 \mathrm{~L}$ copper alembic distillation equipment to be subjected to steam distillation. The essential oil and 


\begin{tabular}{|c|c|c|c|c|c|c|}
\hline \multirow{5}{*}{\multicolumn{2}{|c|}{$\begin{array}{c}\text { Thymus vulgaris L. var. } \\
\text { Donne Valley }\end{array}$}} & Year $-x$ & \multicolumn{2}{|c|}{ Phenological stage - $\mathrm{y}$} & \multicolumn{2}{|c|}{ Annotation } \\
\hline & & 2017 & \multicolumn{2}{|c|}{ before flowering } & \multicolumn{2}{|c|}{ TDL-2017-BF } \\
\hline & & 2017 & \multicolumn{2}{|c|}{ after flowering } & \multicolumn{2}{|c|}{ TDL-2017-AF } \\
\hline & & 2018 & \multicolumn{2}{|c|}{ before flowering } & \multicolumn{2}{|c|}{ TDL-2018-BF } \\
\hline & & 2018 & \multicolumn{2}{|c|}{ after flowering } & \multicolumn{2}{|c|}{ TDL-2018-AF } \\
\hline Nr. Crt. & \multicolumn{2}{|c|}{ Compound } & TDL 2017 BF & $\begin{array}{c}\text { TDL } 2017 \\
\text { AF }\end{array}$ & TDL 2018 BF & $\begin{array}{c}\text { TDL 2018 } \\
\text { AF }\end{array}$ \\
\hline 1 & \multicolumn{2}{|c|}{ alpha-Thujene } & 0.58 & 0.96 & 0.99 & 1.37 \\
\hline 2 & \multicolumn{2}{|c|}{ alpha-Pinene } & 0.34 & 0.71 & 0.49 & 0.8 \\
\hline 3 & \multicolumn{2}{|c|}{ Camphene } & 0.22 & 0.58 & 0.56 & 1.34 \\
\hline 4 & \multicolumn{2}{|c|}{ 3-Octanone } & 2.09 & 2.41 & 2.32 & 3.78 \\
\hline 5 & \multicolumn{2}{|c|}{ 1-Octen-3-ol } & 0.44 & 0.31 & 0.93 & nd \\
\hline 6 & \multicolumn{2}{|c|}{ beta-Pinene } & 1.04 & 0.69 & 1.36 & 0.9 \\
\hline 7 & \multicolumn{2}{|c|}{ beta-Myrcene } & nd & nd & 0.75 & 0.55 \\
\hline 8 & \multicolumn{2}{|c|}{ 3-Octanol } & 0.36 & 0.36 & nd & nd \\
\hline 9 & \multicolumn{2}{|c|}{ alpha-Phellandrene } & 0.16 & 0.27 & 0.54 & nd \\
\hline 10 & \multicolumn{2}{|c|}{ alpha- Terpinolen } & 1.38 & 1.82 & 2.41 & 1.84 \\
\hline 11 & \multicolumn{2}{|c|}{ p-Cymene } & 10.59 & 21.58 & 7.63 & 30.75 \\
\hline 12 & \multicolumn{2}{|c|}{ 1,3,8-p-Menthatriene } & 0.51 & 0.79 & 0.87 & 0.7 \\
\hline 13 & \multicolumn{2}{|c|}{ gamma-Terpinene } & 11.88 & 9.46 & 18.67 & 9.74 \\
\hline 14 & \multicolumn{2}{|c|}{ Sabinene hydrate } & 0.69 & 3.81 & 0.72 & 3.05 \\
\hline 15 & Lin & & 0.1 & 0.18 & nd & nd \\
\hline 16 & endo- & & 0.49 & 1.2 & nd & nd \\
\hline 17 & Isob & & 0.25 & 0.41 & 0.88 & 1.08 \\
\hline 18 & cis-Sabin & ydrate & nd & nd & 0.89 & 1.5 \\
\hline 19 & Thymol n & lether & 4.94 & 9.36 & 4.81 & 5.96 \\
\hline 20 & Carvacrol & l ether & 5.13 & 3.96 & 2.88 & 5.86 \\
\hline 21 & & & 42.35 & 28.04 & 46.74 & 24.86 \\
\hline 22 & $\mathrm{Car}$ & & 5.67 & 3.78 & 2.85 & 2.91 \\
\hline 23 & beta-Bo & lene & 0.17 & 0.17 & nd & nd \\
\hline 24 & Caryol & & 3.54 & 2.82 & 1.02 & nd \\
\hline 25 & beta-C & & 0.12 & 0.06 & nd & 1.27 \\
\hline 26 & Hum & & 0.18 & 0.14 & nd & nd \\
\hline 27 & gamma-: & olene & 0.29 & 0.23 & 0.71 & nd \\
\hline 28 & Germa & & 0.13 & 0.46 & nd & 0.63 \\
\hline 29 & gamma & lene & 0.37 & 0.47 & nd & nd \\
\hline 30 & Isocaryc & lene & 4.38 & 2.94 & 0.98 & 1.11 \\
\hline 31 & Isogerm & D & 0.51 & 0.29 & nd & nd \\
\hline 32 & delta-C & & 0.68 & 0.39 & nd & nd \\
\hline 33 & Caryophy & oxide & 0.13 & 0.35 & nd & nd \\
\hline 34 & Hydrothy & inone & 0.29 & 1 & nd & nd \\
\hline
\end{tabular}

Table 1

ANNOTATIONS FOR DIFFERENT THYMUS VULGARISL. VAR. DONNE VALLEYSAMPLES nd - not detected.

hydrolate mixture were placed in a separator funnel and left to separate in two layers based on their density. The collected pure essential oil was stored at $4^{\circ} \mathrm{C}$ in brown glass vials until further analysis.

\section{Annotations}

Essential oil of Thymus vulgaris L. var. Donne Valley was denoted as TDL-x-y, where $x$ stands for year of harvest and y stands for phenological stage, as is presented in table 1.

\section{GC-MS analysis}

The chemical composition for all TDL-x-y essential oil samples were determined by gas chromatography
(Shimadzu 2010, Kyoto, Japan) coupled with mass spectrometer (TQ 8040, Shimadzu, Kyoto, Japan). The column was an Optima 1MS+WAX column ( $30 \mathrm{~m} \times 0.25$ $\mathrm{mm}$ i.d., $0.25 \mu \mathrm{m}$ film thickness, Macherey-Nagel, Duren, Germany). As a carrier gas, He was used at $1 \mathrm{~mL} \mathrm{~min}^{-1}$. The initial temperature of the oven was $70^{\circ} \mathrm{C}$ (for $11 \mathrm{~min}$ ); it was raised to $190^{\circ} \mathrm{C}$ at a rate of $5^{\circ} \mathrm{C} \mathrm{min}-1$, then to $240^{\circ} \mathrm{C}$ at a rate of $20^{\circ} \mathrm{C} \mathrm{min}^{-1}$ and left for $5 \mathrm{~min}$. Injector temperature was $250^{\circ} \mathrm{C}$ and MS source temperature was $200^{\circ} \mathrm{C}$. The volume of injection was $1 \mu \mathrm{L}$ with a split ratio of 10:1. TDL-x-y compounds have been identified based on their mass spectra using NIST 14 library and Wiley 09 library. 


\section{ATR-FTIR analysis}

Essential oil samples were analyzed by FT-IR and their spectra were recorded using a Bruker Vertex 70 spectrophotometer equipped with an ATR cell on the 600$4000 \mathrm{~cm}^{-1}$ wavelength range, a $4 \mathrm{~cm}^{-1}$ resolution and 32 scans. Background measurements were performed before each analysis. Normalization (min-max) and baseline corrections were applied, and processing of the spectra was performed using OPUS software.

\section{Results and discussions}

Essential oil composition

The yield for extraction of essential oils TDL-2017-BF/ AF was $\sim 0.9 \%$ and for TDL-2018-BF/AF was $\sim 0.3 \%$. The chemical compositions of those oils are presented in table 2.

In the samples 34 constituents were identified; sixteen of them have been found to be present in all stages. Thymol was the major component of all essential oils, and the highest amount (46.74 \%) was observed in TDL $2018 \mathrm{BF}$. Other constituents were also identified in significant amounts in essential oils analyzed: p-cymene (30.75\%), gama-terpinene (18.67\%), thymol methyl ether (9.36\%), carvacrol methyl ether $(5.86 \%)$, carvacrol $(5.67 \%)$, isocaryophyllene $(4.38 \%)$, sabinene hydrate $(3.81 \%)$, 3octanone (3.78\%), alpha-terpinolene (1.84\%), beta-pinene (1.36\%), camphene (1.34\%).

Based on literature, essential oils of Thymus species have been known to have six chemotypes, containing as major component a phenolic derivative (thymol or carvacrol) or an alcohol (linalool, geraniol, thujanol-4 or áterpineol). It is difficult to have a precise delimitation of chemotypes, therefore for essential oils, the distinction is done in accordance to the major compound detected in the essential oil, butone should also take into consideration the biogenetic pathways [26, 27]. During phenological stages the chemical composition of the essential oil changes, influencing the percentage of major compounds. Differences were observed in the essential oil chemical composition before and after flowering stages from two consecutive years taken into this study. Differences are depicted in figure 1 and 2 .
As it can be observed in figure 1, the chemical composition of TDL-2017-BF/AF changes between flow ering and after flowering stages influencing the percentage of several compounds either by increasing or decreasing it. Thymol, which is the major compound found in TDL essential oil before flowering, decreased from $42.35 \%$ to $28.04 \%$ after flowering. Furthermore, other compounds decreased in the same pattern, as follows: gamma-terpinene (11.88\% to $9.46 \%)$, carvacrol $(5.67 \%$ to $3.78 \%)$, carvacrol methyl ether $(5.13 \%$ to $3.96 \%)$, isocaryophyllene ( $4.38 \%$ to $2.94 \%$ ), caryophyllene (3.54\% to $2.82 \%)$, beta-pinene $(1.04 \%$ to $0.69 \%)$. The compounds that increased in percentage from before flowering to after flowering stages were the following: p-cymene $(10.59 \%$ to $21.58 \%$ ), thymol methyl ether ( $4.94 \%$ to $9.36 \%)$, sabinene hydrate $(0.69 \%$ to $3.81 \%)$, 3 -octanone $(2.09 \%$ to $2.41 \%)$ and others in smaller rates.

The chemical composition of TDL-2018-BF/AF also have shown modifications mainly in the major compounds. Furthermore, fewer compounds were detected compared with the essential oils from 2017 (table 1).

Thymol, as the major compound found, decreased from $46.74 \%$ to $24.86 \%$ and other compounds decreased as follows: gamma-terpinene (18.67\% to $9.74 \%)$, alphaterpinolen $(2.41 \%$ to $1.84 \%)$, beta-pinene (1.36\% to $0.9 \%)$ and beta-myrcene $(0.75 \%$ to $0.55 \%)$. In contrast, the percentage of the following compounds increased: $p$ cymene from $7.63 \%$ to $30.75 \%$, 3-octanone $(2.32 \%$ to $3.78 \%$ ), sabinene hydrate ( $0.72 \%$ to $3.05 \%)$, thymol methyl ether $(4.81 \%$ to $5.96 \%)$, carvacrol methyl ether $(2.88 \%$ to $5.86 \%)$, carvacrol (2.85\% to $2.91 \%)$, and isocaryophyllene $(0.98 \%$ to $1.11 \%)$. Furthermore, there are different compounds which could not be detected after flowering like: beta-myrcene, 3-octanol, linalool, endoborneol, cissabinene hydrate, beta-bourbonene, humulene, gammaelemene, isogermacrene $D$, delta-cadinene, caryophyllenne oxide and hydrothymoquinone.

As it is presented in table 1 and figures 1 and 2, the chemical composition of Thymus vulgaris $L$. var. Donne Valley essential oil changes from one phenological stage to another giving options on choosing the ideal harvesting time.
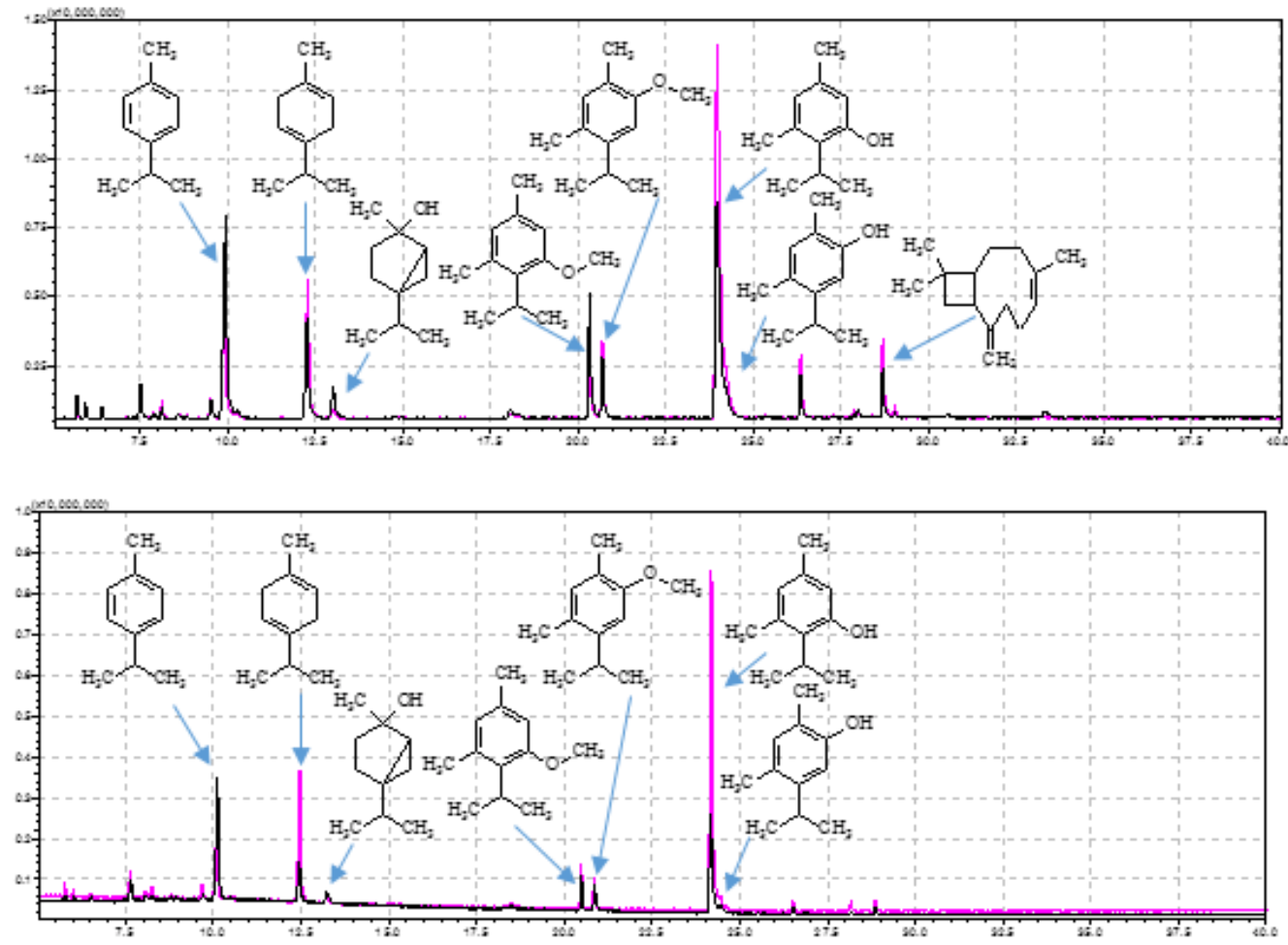

Fig.1. The chemical composition of TDL-2017. Pink - before flowering (BF), Black - after flowering (AF)

Fig.2. The chemical composition of TDL-2018 essential oils obtained from herba before flowering (pink) and after flowering (black) 


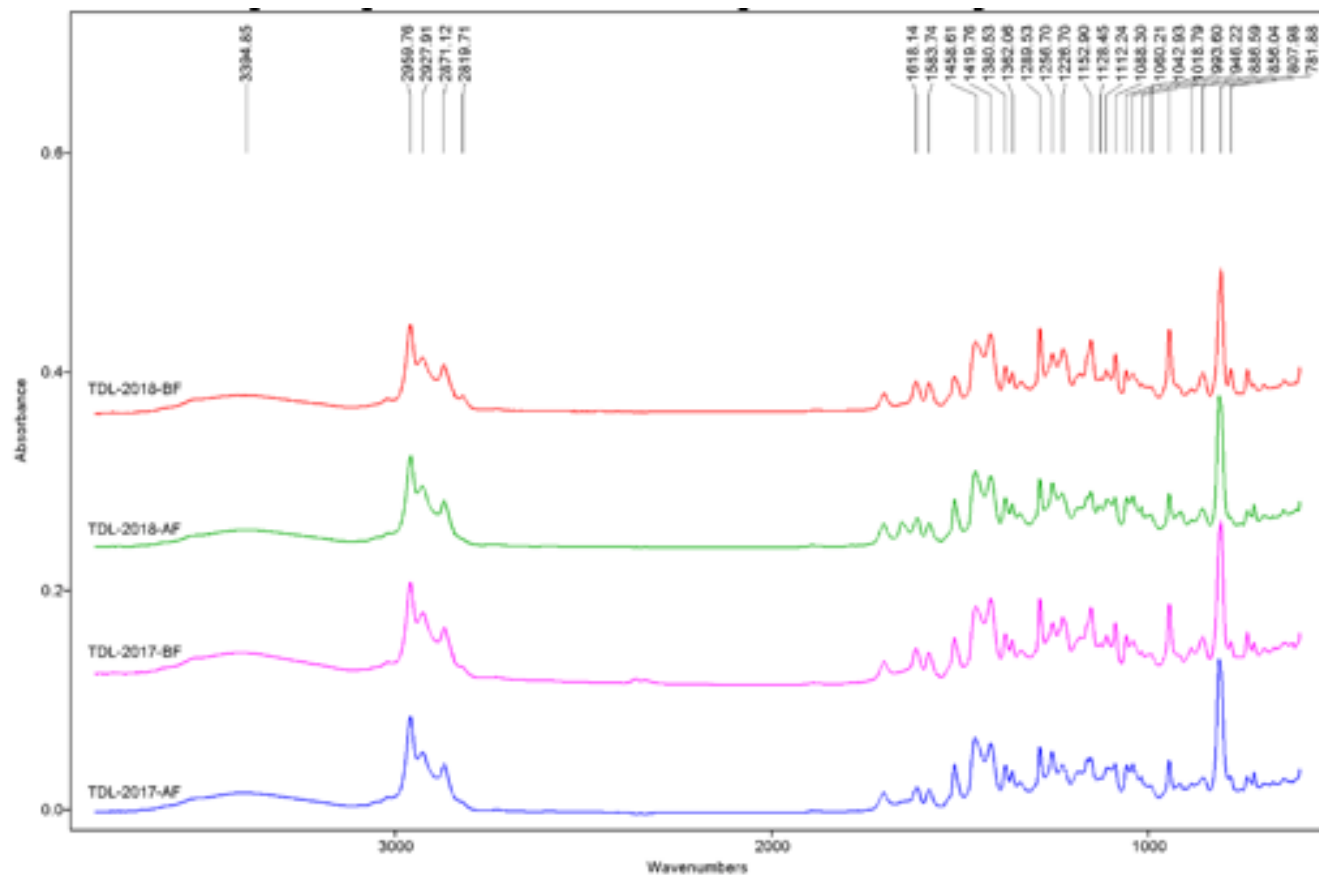

Fig.3. FT-IR spectra of TDL-x-y essential oil samples

\section{ATR-FTIR analysis}

ATR-FTIR spectroscopy is a simple, sensitive, fast and non-destructive method of analysis based on the vibrational spectra recording. As it is known, all major compounds present in essential oils dominate the obtained vibration spectra, while low concentration compounds, hardly influence the ATR-FTIR pathway [29]. In accordance with GC-MS analysis results, the major compounds found in TDL-x-y essential oils are: thymol, $\gamma$-terpinene and $p$ cymene. A smaller impact could be attributed to: 3octanone, $\alpha$-terpinolene, thymol methyl ether, carvacrol methyl ether, carvacrol and isocaryophyllene.

The ATR-FTIR spectra recorded for the TDL-x-y essential oil samples are presented in figure 3 , with characteristic bands added. Because essential oils are complex mixtures of compounds, the absorption spectrum for some compounds overlap.

The band seen at $807 \mathrm{~cm}^{-1}$ is attributed to $\mathrm{C}-\mathrm{H}$ out-ofplane waging vibrations from thymol and is important in distinguishing the substitution on the aromatic ring for the isomeric compounds carvacrol and thymol. Carvacrol presents a vibration band at $812 \mathrm{~cm}^{-1}$ [28-30]. Furthermore, thymol characteristic bands were identified at: $946 \mathrm{~cm}^{-1}$ (wagging vibration of 1:2:4 substitution), $1152 \mathrm{~cm}^{-1}$ (metasubstitution) and on $3200-3600 \mathrm{~cm}^{-1}(-\mathrm{OH}$ stretching vibration). Furthermore, the intense bands present in the spectrum at 807, 946, 1042, 1088, 1152 and $1289 \mathrm{~cm}^{-1}$ indicate thymol as the main component in TDL-X-y essential oil [28].

Other major compounds identified by GC-MS analysis and confirmed by the presence in the ATR-FTIR spectra were identified as follows: $p$-cymene with characteristic bands recorded at 1060 and $1018 \mathrm{~cm}^{-1}$ attributed to parasubstitution [31]; $\gamma$-terpinene with characteristic signals recorded at 781, 946 and $2819 \mathrm{~cm}^{-1}$ [32]. For other terpenoids the following bands have been attributed: caryophyllene at $885 \mathrm{~cm}^{-1}, \beta$-pinene at $873 \mathrm{~cm}^{-1}, \alpha$-pinene at $886 \mathrm{~cm}^{-1}$, carvacrol at $812 \mathrm{~cm}^{-1}$ and $\alpha$-terpinolen at 781 $\mathrm{cm}^{-1}$ [31].

\section{Conclusions}

The present study revealed differences between the chemical compositions of essential oils obtained from plants harvested in different phenological stages and vegetation cycles. For this purpose, essential oils were obtained and analyzed before and after flowering stages in two different years (2017 and 2018). Through GC-MS and ATR-FTIR analysis the chemical composition of Thymus vulgaris L. var. Donne Valley essential oils was determined. Thymol was found as the major component with a high percentage $46.74 \%$ in essential oil obtained before flowering in 2018. This percentage changed through phenological stages and vegetation cycles. Due to the differences between chemical composition in phenological stages and vegetation cycles, and taking into consideration the desired compound of interest, the harvesting time could plan ahead.

Because there is an increasing demand on natural bioactive compounds derived from medicinal plants, Thymus vulgaris L. var. Donne Valley is a rich source of phenolic monoterpenes with many applications (food, pharmaceutical, cosmetic, perfumery, agriculture, etc).

Acknowledgements: This work was supported by the project PN-IIIP1-1.2-PCCDI-2017-0569. Funding for some of the equipment used in the study has been provided by the European Commission and the Romanian Government (project POSCCE 621/2014).

\section{References}

1.APOSTOL L., BERCA L., MOSOIU C., BADEA M., BUNGAU S., OPREA O.B., CIOCA G., Rev. Chim.(Bucharest), 69, no. 6, 2018, p. 1398. 2.COPOLOVICI, D., BUNGAU, S., BOSCENCU, R, TIT, D. M., COPOLOVICl, L., Rev. Chim. (Bucharest), 68, no. 3, 2017, p. 507. 3.COPOLOVICI, L., NIINEMETS, U., Plant Cell Environ., 2010, 33, p. 1582.

4.GITEA, D., VICAS, S., GITEA, M.A., NEMETH, S., TIT, D.M., PASCA, B., PURZA, L., IOVAN, C. Rev. Chim.(Bucharest), 69, no. 2, 2018, p. 305. 5.MOSTEANU, D., BARSAN, G., GIURGIU, L., EPURE G., Rev. Chim.Bucharest, 60, nr. 3, 2009, p. 290.

6.MOSTEANU, D., BARSAN, G., OTRISAL, P., GIURGIU, L ., OANCEA, R., Rev. Chim.(Bucharest), 68, no. 11, 2017, p. 2499.

7.TOOME, M., RANDJAARV, P., COPOLOVICI, L., NIINEMETS, U., HEINSOO, K., LUIK, A., NOE, S.M., Planta, 232, nr. 1, 2010, p. 235. 8.BUNGAU S. G., POPA V.-C., Transylv. Rev., XXIV, nr. 3, 2015, p. 3. 9.STAHL-BISKUP, E., SAEZ, F., Essential oil chemistry of the genus Thymas - a global view, in Medicinal and Aromatic Plants - Industrial Profiles, Ed. by LANSKY, E.P., CRC Press, London and New York, 2002, p. 75-124. 
10.VAICIULYTE, V., BUTKIENE, R., LOZIENE, K., Phytochem., 128, 2016, p. 20.

11.GAVAHIAN, M., FARAHNAKY, A., J AVIDNIA, K., MAJ ZOOBI, M., Innov. Food Sci. Emerg. Technol., 14, 2012, p. 85.

12.ASADOLLAHI-BABOLI, M., AGHAKHANI, A., BIKDELOO, V., Food Anal. Methods, 9, nr. 2, 2016, p. 528.

13.MANDAL, S., DEBMANDAL, M., Essential Oils in Food Preservation, Flavor and Safety, Chapter 94, Ed. by VICTOR, R., Academic Press, San Diego, 2016, p. 825-834.

14.SATYAL, P., MURRAY, B.L., MCFEETERS, R.L., SETZER, W.N., Foods, 5, nr. 4, 2016, p. 12.

15.ASSIRI, A.M., ELBANNA, K., ABULREESH, H.H., RAMADAN, M.F., J. Oleo Sci., 65, nr. 8, 2016, p. 629.

16.ZRIG, A., TOUNEKTI, T., GAWAD, H.A., HEGAB, M.M., OUELED ALI, S., KHEMIRA, H., Ind. Crops Prod., 91, 2016, p. 223.

17.PIRBALOUTI, A.G., HASHEMI, M., GHAHFAROKHI, F.T., Ind. Crops Prod., 48, 2013, p. 43.

18.VARGA, E., BARDOCZ, A., BELAK, A., MARAZ, A., BOROS, B., FELINGER, A., BOSZORMENYI, A., HORVATH, G., Farmacia, 63, nr. 3, 2015, p. 357.

19.NEZHADALI, A., NABAVI, M., RAJABIAN, M., AKBARPOUR, M., POURALI, P., AMINI., F., Beni-Suef Univ. J. Appl. Sci., 3, nr. 2, 2014, p. 87.

20.NIKOLIC, M., JOVANOVIC, K.K., MARKOVIC, T., MARKOVIC, D., GLIGORIJ EVIC, N., RADULOVIC, S., SOCOVIC., M., Ind. Crops Prod., 61, 2014, p. 225.
21.TOHIDI, B., RAHIMMALEK, M., ARZANI, A., Food Chem., 220, 2017, p. 153.

22.TRIPATHI, N.N., MISHRA, A.K., TRIPATHI, S., P. Natl. A. Sci. India B, 81, 2011, p. 23.

23.THOMPSON, J.D., MANICACCI, D., TARAYRE, M., Biosci. J., 48, nr. 10, 1998, p. 805.

24.CLARKE, S., Essential Chemistry for Aromatherapy, $2^{\text {nd }}$ Ed., Ed. by CLARK, S., Churchill Livingstone, Elsevier, 2009.

25.STAHL-BISKUP, E., SAEZ, F., Essential oil polymorphism in the genus Thymus, in Thyme. The Genus Thymus, $1^{\text {st }}$ Ed., Ed. by Lansky, E.P., CRC Press, London, 2003, p. 125-143.

26.CHIZZOLA, R., Regular Monoterpenes and Sesquiterpenes (Essential Oils), in Natural Products: Phytochemistry, Botany and Metabolism of Alkaloids, Phenolics and Terpenes, Ed. by RAMAWAT, K.G., MERILLON, J.-M., Springer Berlin Heidelberg, 2013, p. 29733008.

27.RUSTAIEE, A.R., MIRAHMADI, S.F., SEFIDKON, F., TABATABEI, M.F., OMIDBAIGI, R., J. Essent. Oil Bear. PI., 14, nr. 5, 2011, p. 625.

28.VALDERRAMA, A., DE GANTE, C.R., Am. J. Anal. Chem., 8, nr. 11, 2017, p. 726.

29.TOPALA, C.M., TATARU, L.D., Rev. Chim.(Bucharest), 67, no. 5, 2016, p. 842.

30.SCHULZ, H., BARANSKA, M., Vb. Spectrosc., 43, nr.1, 2007, p. 13. 31.SCHULZ, H.,OZKAN, G., BARANSKA, M., KRUGER, H., OZCAN, M., Vb. Spectrosc., 39, nr. 2, 2005, p. 249.

32.COATES, J., Interpretation of infrared spectra, a practical approach, in Encyclopedia of Analytical Chemistry, Ed. by MEYERS, R.A., John Wiley \& Sons Ltd., New Jersey, 2006, p. 10815-10837.

Manuscript received: 11.09 .2018 